\title{
Literasi Matematika Tahap Merumuskan Masalah Secara Matematis Siswa kemampuan Tinggi dalam Memecahkan Masalah Matematika Kelas VIII
}

\author{
Khanifah $^{1}$, Sutrisno $^{2}$, \& FX.Didik Purwosetiyono ${ }^{3}$ \\ ${ }^{1,2,3}$ Universitas PGRI Semarang
}

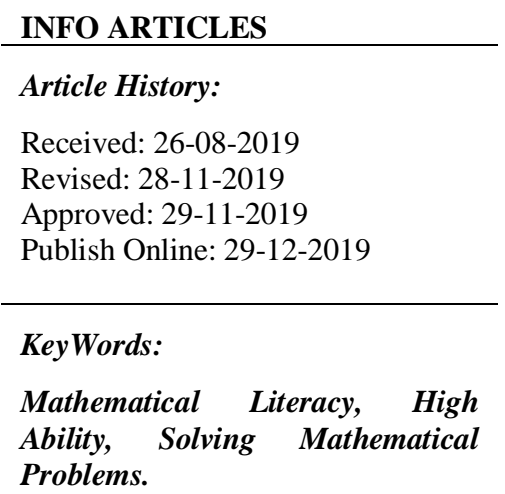

Problems.

This article is licensed under a Creative Commons AttributionShareAlike 4.0 International License.

\begin{abstract}
The purpose of this study is to determine the level of mathematical literacy on students with high ability in mathematics problems solving in VIII grade of Junior High School (SMP). The study was conducted at SMP Negeri 3 Purwodadi in 2018/2019 academic year. This research is a descriptive qualitative research. Data collection was done by tests, interviews, and documentation. The research subjects were chosen by three students, all of whom are students with high literacy mathematical abilities. The results showed that the mathematical literacy process of students at the stage of formulating mathematical problems was identifying the mathematical aspects of a problem context in real life and identifying known variables; determine mathematical models and simplify problems; and determine aspects of mathematical concepts, facts or procedures of a problem.
\end{abstract}

\begin{abstract}
Abstrak:Tujuan penelitian ini adalah mengetahui tingkat literasi matematika siswa kemampuan tinggi dalam memecahkan masalah matematika kelas VIII SMP. Penelitian dilakukan di SMP Negeri 3 Purwodadi pada tahun ajaran 2018-2019. Penelitian ini merupakan penelitian kualitatif deskriptif. Pengumpulan data dilakukan dengan tes, wawancara, dan dokumentasi. Subjek penelitian dipilih tiga siswa, yang ketiganya merupakan siswa dengan literasi matematika kemampuan tinggi. Hasil penelitian menunjukkan bahwa proses literasi matematika siswa pada tahap merumuskan masalah secara matematis yaitu mengidentifikasi aspek matematika dari suatu konteks masalah di kehidupan nyata dan mengidentifikasi variabel yang diketahui; menentukan model matematika dan menyederhanakan masalah; serta menentukan aspek konsep matematika, fakta, atau prosedur dari suatu masalah.
\end{abstract}

Correspondence Address:Jln. Sidodadi Timur No. $24-$ Dr. Cipto, Semarang, Indonesia; e-mail: sutrisnojr@upgris.ac.id.

How to Cite (APA 6 $^{\text {th }}$ Style): Khanifah, Sutrisno, \& Purwosetiyono, F.X.D. 2019. Literasi Matematika Tahap Merumuskan Masalah Secara Matematis Siswa Kemampuan Tinggi dalam Memecahkan Masalah Matematika Kelas VIII.JKPM (Jurnal Kajian Pendidikan Matematika), 5 (1): 37-48.

Copyright: Khanifah, Sutrisno, \& Purwosetiyono, F.X.D, (2019)

Competing Interests Disclosures: The authors declare that they have no significant competing financial, professional or personal interests that might have influenced the performance or presentation of the work described in this manuscript. 


\section{PENDAHULUAN}

Di era globalisasi perlu mempersiapkan generasi muda yang andal dan memiliki pemikiran yang kritis, sistematis, logis, kreatif serta kemauan untuk bekerja sama secara efektif sejak dini. Pendidikan merupakan sarana penting untuk menciptakan sumber daya manusia (SDM) yang kompetitif guna untuk menjamin kelangsungan pembangunan suatu bangsa. Pendidikan diharapkan mampu membekali siswa kemampuan untuk menerapkan pengetahuannya dalam kehidupan sehari-hari. Kemampuan tersebut diharapkan dapat dikembangkan dalam pendidikan melalui mata pelajaran yang diajarkan di sekolah (Sari, 2015). Matematika merupakan satu di antara bidang studi yang selalu ada di setiap jenjang pendidikan di Indonesia

Literasi matematika menurut OECD (2014) adalah kemampuan seseorang untuk merumuskan, menerapkan, dan menafsirkan matematika dalam berbagai konteks, termasuk kemampuan melakukan penalaran secara matematis dan menggunakan konsep, prosedur, dan fakta untuk menggambarkan, menjelaskan atau memperkirakan fenomena atau kejadian. Kemampuan literasi matematika membantu seseorang untuk memahami peran atau kegunaan matematika di dalam kehidupan sehari-hari dan sekaligus menggunakannya untuk membuat keputusan-keputusan yang tepat atas berbagai permasalahan atau fenomena yang terjadi (Asmara, 2017).

Pentingnya literasi matematika ini, ternyata belum sejalan dengan prestasi siswa Indonesia di mata Internasional. Indonesia dalam taraf internasional dipandang belum mampu melahirkan generasi yang berliterasi. Saat ini terdapat dua asesmen utama berskala internasional yang menilai kemampuan matematika dan sain siswa, yaitu PISAdan TIMSS. PISA dilaksanakan secara regular tiga tahun sekali sejak tahun 2000 untuk mengetahui literasi siswa usia 15 tahun dalam matematika, sains, dan membaca. Sedangkan TIMSS dilaksanakan secara regular sekali dalam empat tahun sejak 1994--1995.

Indonesia sendiri telah mengikuti studi PISA sejak tahun 2000 dan waktu itu studi PISA diikuti oleh 41 negara dan Indonesia mendapat peringkat ke-39 dengan skor 367 untuk studi literasi matematika. Pada tahun 2003, studi PISA diikuti oleh 40 negara dan Indonesia mendapat peringkat ke-38 dengan skor untuk literasi matematika, yaitu hanya satu peringkat lebih tinggi dari tinggi Tunisia. Pada tahun 2006 studi PISA diikuti oleh 57 negara peserta dan menempatkan Indonesia pada posisi ke-50 dengan skor 391 untuk literasi matematika. Pada tahun 2009 studi PISA diikuti sebanyak 65 negara dan Indonesia mendapat peringkat ke-60. Pada tahun 2012, studi PISA diikuti oleh 70 negara dan Indonesia mendapat peringkat terendah nomor 2 yaitu 68 dari 70 negara. Studi PISA yang dilakukan pada tahun 2015 menempatkan Indonesia pada peringkat 62 dari 72 negara dengan nilai rata-rata 403 termasuk masih rendah dibandingkan dengan negara lain yang diperoleh paling tinggi oleh singapura (Kemendikbud, 2016).

PISA membagi capaian kemampuan literasi siswa dalam enam tingkatan kecakapan, mulai level 1 (terendah) sampai level 6 (tertinggi) untuk matematika dan sains. Level-level tersebut menggambarkan tingkat penalaran dalam menyelesaikan masalah. Mayoritas siswa Indonesia belum mencapai level 2 untuk matematika $(75,7 \%)$ dan sains $(66,6 \%)$, dan yang memprihatinkan $42,3 \%$ siswa bahkan belum mencapai level kecakapan terendah (level 1) untuk matematika dan 24,7\% untuk sains (OECD, 2013). Hasil penelitian yang berkaitan dengan PISA menunjukkan masih rendahnya kemampuan literasi matematika siswa di beberapa jenis konten maupun konteks yang sama hal ini disebabkan oleh banyak faktor antara lain variasi soal dan materi yang dipilih (Hawa, 2014; Aini, 2014).Tidak hanya melihat hasil penelitian 
PISA yang menunjukkan rendahnya kemampuan literasi matematika tetapi juga peneliti telah mengujicobakan soal PISA ke salah satu siswa SMP kelas VIII yang disajikan pada Gambar 1.

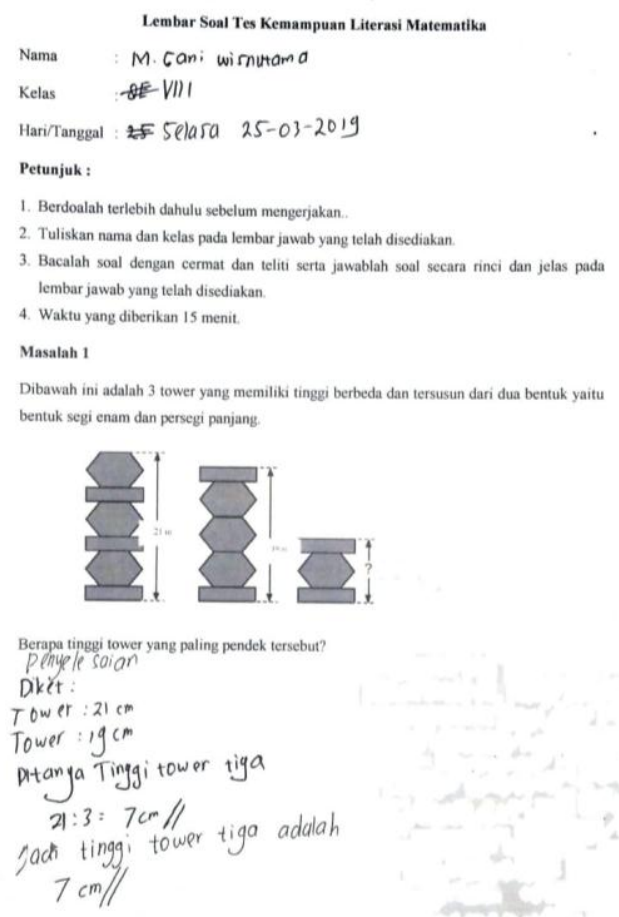

\section{Gambar 1. Soal Tes Kemampuan Literasi Matematika}

Dari hasil uji coba yang telah dilakukan, terlihat siswa belum maksimal dalam mencapai tahapan proses literasi matematika. Saat kita ingin menguji kemampuan literasi, ada beberapa materi yang dijadikan acuan untuk mengukur tingkat kemampuan pemecahan masalah matematika siswa seperti literasi dalam materi geometri, statistik, aljabar, dan bilangan.

Berdasar pada uraian di atas, dapat dilihat gambaran secara global mengenai keadaan tentang kemampuan literasi khususnya literasi matematika yang rendah. Oleh karena itu, peneliti mencoba kembali apakah benar keadaan secara global yang ada di Indonesia mewakili keadaan yang ada sebenarnya di setiap sekolah dengan upaya pemberian soal yang serupa dengan tes PISA. Wardani (2005) mengemukakan bahwa soal-soal PISA sangat menuntut kemampuan penalaran dan pemecahan masalah. Seorang siswa dikatakan mampu menyelesaikan masalah apabila ia dapat menerapkan pengetahuan yang telah diperoleh sebelumnya ke dalam situasi baru yang belum dikenal.Kemampuan seperti inilah bisa disebut sebagai keterampilan berpikir tingkat tinggi. Sehingga dalam penelitian ini peneliti hanya akan mengambil subjek siswa berkemampuan tinggi. Hal inilah yang membuat peneliti tertarik untuk melakukan penelitian mengenai literasi matematika siswa dalam memecahkan masalah matematika kelas VIII pada siswa kemampuan tinggi.

\section{METODE}

Jenis penelitian ini adalah deskriptif kualitatif. Subyek penelitian ini adalah siswa berkemampuan matematika tinggi pada kelas VIII C SMP Negeri 3 Purwodadi. Pengambilan sampel dalam penelitian kualitatif menggunakan teknik purposive sampling. Pelaksanaan tes dilakukan pada jam mata pelajaran 
yang telah ditentukan oleh wakil kepala kurikulum SMP Negeri 3 Purwodadi. Fokus dalam penelitian ini yaitu kemampuan literasi matematika, khususnya pada tahap merumuskan masalah secara matematis. Tes awal untuk mengategorikan kemampuan matematika siswa diikuti oleh kelas VIII C. Kategori tersebut terdiri dari 3 tingkatan,yaitu kategori rendah, sedang, dan tinggi. Kriteria penentuan kategori tersaji pada Tabel 1.

Tabel 1. Interval Nilai dari Tiap-Tap Kategori

\begin{tabular}{cc}
\hline Interval Nilai & Kategori \\
\hline$X \geq \bar{X}+S$ & Tinggi \\
$\bar{X}-S \leq X<\bar{X}+S$ & Sedang \\
$X<\bar{X}-S$ & Rendah \\
\hline
\end{tabular}

Setelah siswa tergolongkan pada masing-masing tingkatan, diambil 3 subjek dengan kategori tinggi. Dalam pengambilan 3 subjek kategori tinggi tersebut dilihat dari hasil tes dan pertimbangan yang diberikan oleh guru matematika, sehingga hasil pengambilan subyek dapat dipertanggungjawabkan. Metode yang digunakan untuk pengambilan data yaitu metode tes, wawancara, dan dokumentasi. Dalam metode tes, tes yang digunakan berupa tes kemampuan matematika dan tes untuk mengukur tingkat literasi matematika siswa.Instrumen dalam penelitian ini adalah peneliti, tes, dan pedoman wawancara. Analisis data dilakukan dengan reduksi data, penyajian data, dan penarikan kesimpulansedangkan pengujian keabsahan data digunakan teknik triangulasi teknik, sumber, dan waktu.

\section{HASIL}

Penelitian ini memeroleh data mengenai literasimatematika siswa yang dilaksanakan di SMP Negeri 3 Purwodadi, khususnya pada siswa dengan literasi matematika kemampuan tinggi.Hasil analisis jawaban tesliterasi matematika dari subyek penelitian RAM, NZC, dan WNF padapengambilan data pertama dan kedua, khususnya tahapan merumuskan masalah secara matematis tersaji pada Gambar 2, Gambar 3, Gambar 4,Gambar 5, Gambar 6, dan Gambar 7.

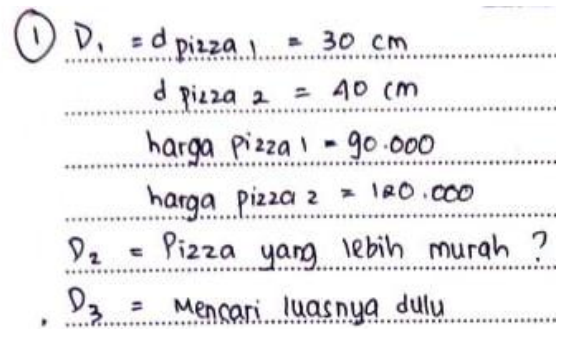

Gambar 2. Hasil Tes Tertulis 1 Subjek RAM

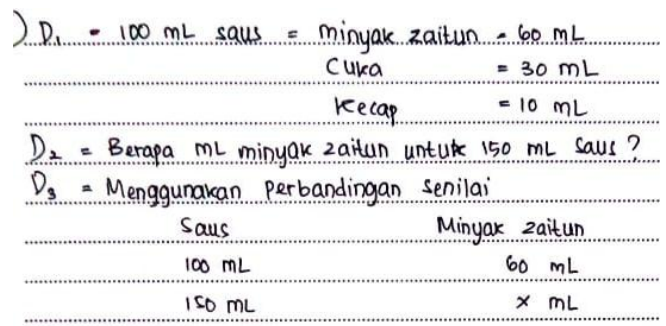

Gambar 3. Hasil Tes 2 Tertulis Subjek RAM

Hasil yang didapat dari tes tertulis, subyek RAM mampu merumuskan masalah secara matematis tetapi belum lengkap. Subjek RAM mampu mengenali masalah dengan mengetahui harga tiap-tiap pizza dan mengetahui hal yang ditanyakan pada soal,tetapi subjek RAM tidak menentukan model matematikanya. 


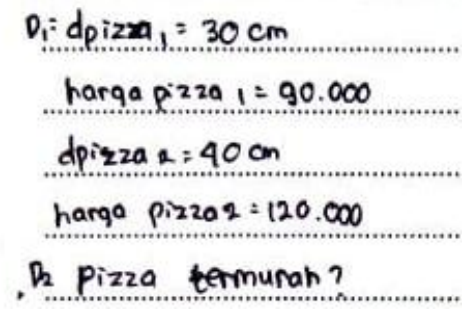

Gambar 4. Hasil Tes Tertulis 1 Subjek NZC

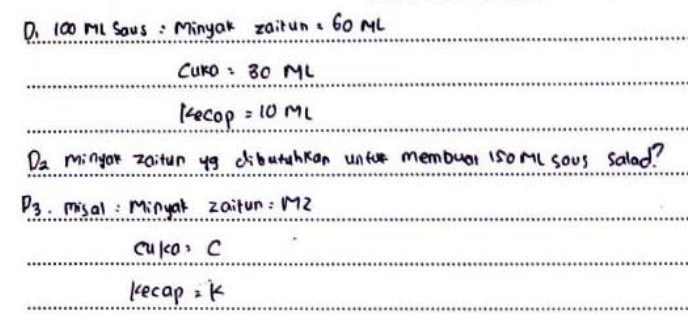

Gambar 5. Hasil Tes2 Tertulis Subjek NZC

Hasil yang didapat dari tes tertulis, subjek NZC mampu merumuskan masalah secara matematis namun belum lengkap. Subjek NZC mampu mengenali masalah dengan mengetahui harga tiap-tiap pizza dan mengetahui hal yang ditanyakan pada soal,tetapi subjek NZC tidak menentukan model matematikanya.

D1. dpizza, $=30 \mathrm{~cm}$
dpizza $=40 \mathrm{~cm}$
harga pizza $=90.000$
harga pizza $=120.000$
D2. harga pizza termurah ?

\section{Gambar 6. Hasil Tes Tertulis 1 Subjek WNF}

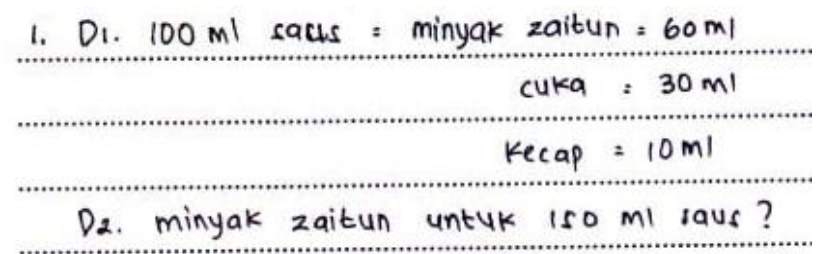

Gambar 7. Hasil Tes Tertulis 2 Subyek WNF

Hasil yang didapat dari tes tertulis, subjek WNF mampu merumuskan masalah secara matematis namun belum lengkap. Subjek WNF mampu mengenali masalah dengan mengetahui harga tiap-tiap pizza dan mengetahui hal yang ditanyakan pada soal tetapi subjek WNF tidak menentukan model matematikanya. Hasil tes tertulis dari setiap subjek penelitian kemudian disandingkan dengan hasil wawancara. Berdasarkan hasil tes tertulisdan wawancara subyek penelitian pada pengambilan data pertama diperoleh triangulasi teknik yang dapat dilihat pada Tabel 2.

\section{Tabel 2. Triangulasi Teknik Pengambilan Data Pertama}

\begin{tabular}{|c|c|c|c|}
\hline Subyek & Hasil Tes Tertulis & Hasil Wawancara & Triangulasi Teknik \\
\hline RAM & $\begin{array}{lr}\text { Subyek RAM } & \text { mampu } \\
\text { merumuskan } & \text { masalah } \\
\text { secara matematis } & \text { namun } \\
\text { belum lengkap } & \end{array}$ & $\begin{array}{l}\text { Subyek RAM mampu } \\
\text { merumuskan masalah secara } \\
\text { matematis namun belum } \\
\text { lengkap }\end{array}$ & $\begin{array}{l}\text { Subyek RAM mampu } \\
\text { merumuskan } \\
\text { secara matematis namun } \\
\text { belum lengkap }\end{array}$ \\
\hline NZC & $\begin{array}{l}\text { Subyek NZC mampu } \\
\text { merumuskan } \\
\text { secara matematis namun } \\
\text { belum lengkap }\end{array}$ & $\begin{array}{l}\text { Subyek NZC mampu } \\
\text { merumuskan masalah secara } \\
\text { matematis namun belum } \\
\text { lengkap }\end{array}$ & $\begin{array}{l}\text { Subyek NZC mampu } \\
\text { merumuskan masalah } \\
\text { secara matematis namun } \\
\text { belum lengkap }\end{array}$ \\
\hline WNF & $\begin{array}{l}\text { Subyek WNF mampu } \\
\text { merumuskan masalah } \\
\text { secara matematis namun } \\
\text { belum lengkap }\end{array}$ & $\begin{array}{l}\text { Subyek WNF mampu } \\
\text { merumuskan masalah secara } \\
\text { matematis namun belum } \\
\text { lengkap }\end{array}$ & $\begin{array}{l}\text { Subyek WNF mampu } \\
\text { merumuskan masalah } \\
\text { secara matematis namun } \\
\text { belum lengkap }\end{array}$ \\
\hline
\end{tabular}

Hasil yang diperoleh dari tes dan wawancara pada pengambilan data pertama menunjukkan bahwa subyek RAM, NZC, dan WNF kurang maksimal dalam melakukan tahapan proses literasi matematika. Diketahui untuk tahapmerumuskan masalah secara matematis,ketiga subjek mampu melakukannyatetapi 
belum lengkap. Untuk mengecek kekonsistenan data,dilakukan pengambilan data kedua melalui tes dan wawancara. Berdasar pada hasil tes tertulis 2 dan wawancara 2 diperoleh pulatriangulasi teknik, yang dapat dilihat pada Tabel 3.

Tabel 3. Triangulasi Teknik Pengambilan Data Kedua

\begin{tabular}{|c|c|c|c|}
\hline Subyek & Hasil Tes Tertulis & Hasil Wawancara & Triangulasi Teknik \\
\hline RAM & $\begin{array}{l}\text { Subyek RAM mampu } \\
\text { merumuskan masalah } \\
\text { secara matematis namun } \\
\text { belum lengkap }\end{array}$ & $\begin{array}{lr}\text { Subyek RAM } & \text { mampu } \\
\text { merumuskan } & \text { masalah } \\
\text { secara matematis } & \text { namun } \\
\text { belum lengkap } & \end{array}$ & $\begin{array}{l}\text { Subyek RAM mampu } \\
\text { merumuskan masalah } \\
\text { secara matematis namun } \\
\text { belum lengkap }\end{array}$ \\
\hline $\mathrm{NZC}$ & $\begin{array}{l}\text { Subyek NZC mampu } \\
\text { merumuskan masalah } \\
\text { secara matematis namun } \\
\text { belum lengkap }\end{array}$ & $\begin{array}{lr}\text { Subyek NZC mampu } \\
\text { merumuskan } & \text { masalah } \\
\text { secara matematis } & \text { namun } \\
\text { belum lengkap } & \end{array}$ & $\begin{array}{l}\text { Subyek NZC mampu } \\
\text { merumuskan masalah } \\
\text { secara matematis namun } \\
\text { belum lengkap }\end{array}$ \\
\hline WNF & $\begin{array}{l}\text { Subyek WNF mampu } \\
\text { merumuskan masalah } \\
\text { secara matematis namun } \\
\text { belum lengkap }\end{array}$ & $\begin{array}{lr}\text { Subyek WNF } & \text { mampu } \\
\text { merumuskan } & \text { masalah } \\
\text { secara matematis } & \text { namun } \\
\text { belum lengkap } & \end{array}$ & $\begin{array}{l}\text { Subyek WNF mampu } \\
\text { merumuskan masalah } \\
\text { secara matematis namun } \\
\text { belum lengkap }\end{array}$ \\
\hline
\end{tabular}

Hasil yang diperoleh dari tes dan wawancarapada pengambilan data kedua menunjukkan bahwa subyek RAM, NZC, dan RAM kurang maksimal dalam melakukan tahapan proses literasi matematika. Diketahui untuk tahapmerumuskan masalah secara matematis, ketiga subyek mampu melakukannya namun belum lengkap.Berdasarkan hasil triangulasi teknik dari ketiga subyek pada pengambilan data pertama dan kedua, diperoleh triangulasi sumber yang ditunjukkan pada Tabel 4.

Tabel 4. Triangulasi SumberPengambilan Data Pertama dan Kedua

\begin{tabular}{|c|c|c|c|c|}
\hline Pengambilan Data & RAM & $\mathrm{NZC}$ & WNF & Triangulasi Sumber \\
\hline Pertama & $\begin{array}{l}\text { Subyek RAM } \\
\text { mampu } \\
\text { merumuskan } \\
\text { masalah secara } \\
\text { matematis } \\
\text { namun belum } \\
\text { lengkap }\end{array}$ & $\begin{array}{l}\text { Subyek NZC } \\
\text { mampu } \\
\text { merumuskan } \\
\text { masalah secara } \\
\text { matematis } \\
\text { namun belum } \\
\text { lengkap }\end{array}$ & $\begin{array}{l}\text { Subyek WNF } \\
\text { mampu } \\
\text { merumuskan } \\
\text { masalah secara } \\
\text { matematis } \\
\text { namun belum } \\
\text { lengkap }\end{array}$ & $\begin{array}{l}\text { Ketiga Subyek mampu } \\
\text { merumuskan masalah } \\
\text { secara matematis namun } \\
\text { belum lengkap }\end{array}$ \\
\hline Kedua & $\begin{array}{l}\text { Subyek RAM } \\
\text { mampu } \\
\text { merumuskan } \\
\text { masalah secara } \\
\text { matematis } \\
\text { namun belum } \\
\text { lengkap }\end{array}$ & $\begin{array}{l}\text { Subyek NZC } \\
\text { mampu } \\
\text { merumuskan } \\
\text { masalah secara } \\
\text { matematis } \\
\text { namun belum } \\
\text { lengkap }\end{array}$ & $\begin{array}{l}\text { Subyek WNF } \\
\text { mampu } \\
\text { merumuskan } \\
\text { masalah secara } \\
\text { matematis } \\
\text { namun belum } \\
\text { lengkap }\end{array}$ & $\begin{array}{l}\text { Ketiga Subyek mampu } \\
\text { merumuskan masalah } \\
\text { secara matematis namun } \\
\text { belum lengkap }\end{array}$ \\
\hline
\end{tabular}

Hasil yang diperoleh dari triangulasi sumber menunjukkan bahwaketiga subyek kurang maksimal dalam melakukan tahapan proses literasi matematika. Diketahui ketiga subyek mampu merumuskan masalah secara matematis tetapi belum lengkap.Berdasar padatriangulasi sumber pada pengambilan data pertama dan kedua diperoleh triangulasi waktu ditunjukkan pada Tabel 5. 
Tabel 5. Triangulasi Waktu

\begin{tabular}{lllll}
\hline \multicolumn{2}{c}{ Triangulasi Sumber 1 } & \multicolumn{2}{c}{ Triangulasi Sumber 2 } & \multicolumn{2}{c}{ Triangulasi Waktu } \\
\hline Ketiga subjek mampu & Ketiga subjek mampu & Ketiga subjek mampu \\
merumuskan masalah & merumuskan masalah & merumuskan & masalah \\
secara matematis namun & secara matematis namun & secara matematis & namun \\
belum lengkap & belum lengkap & & belum lengkap & \\
\hline
\end{tabular}

Hasil yang diperoleh dari triangulasi waktu menunjukkan bahwa ketiga subjekkurang maksimal dalam melakukan tahapan proses literasi matematika. Diketahui untuk tahapan pertamaketiga subyek mampu merumuskan masalah secara matematis tetapi belum lengkap.

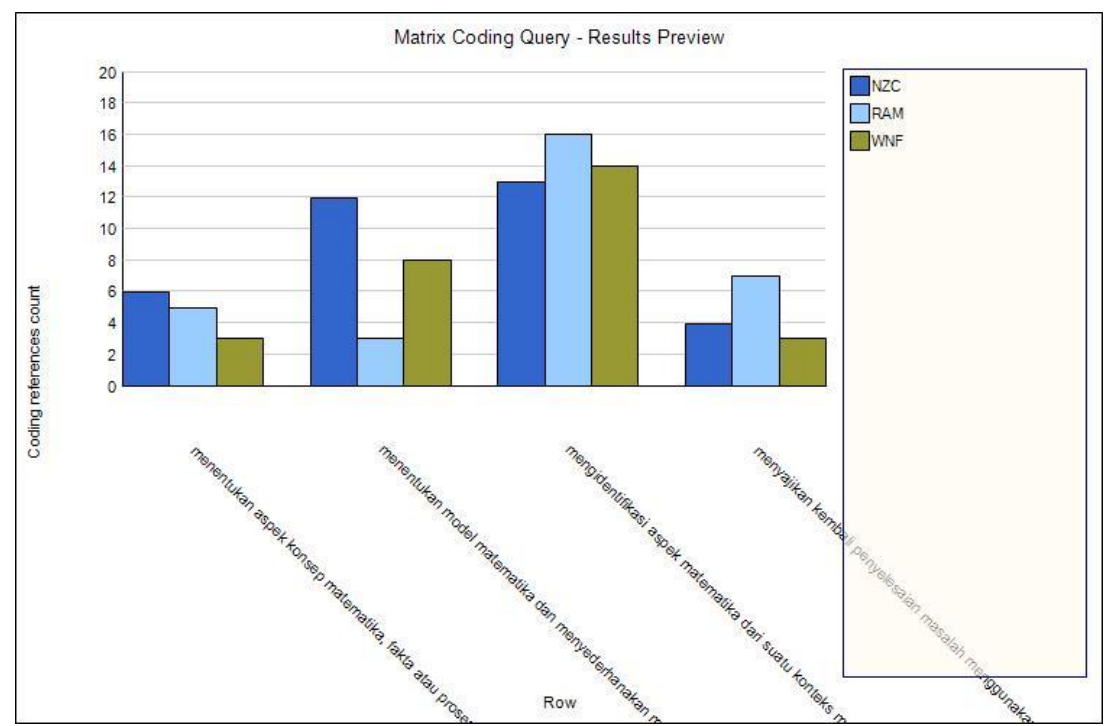

\section{Gambar 8.Matrix CodingLiterasi Matematika pada Tahap Merumuskan Masalah secara Matematis}

Berdasar pada data hasil penelitian yang tergambar dalam Gambar 8menunjukkan bahwa:

1. Pada kemampuan mengidentifikasi aspek matematika dari suatu konteks masalah di kehidupan nyata dan mengidentifikasi variabel yang diketahui, subjek NZC memiliki koding sebanyak 13 kali, subjek RAM sebanyak 16 kali dan subjek WNF sebanyak 14 kali.Terlihat bahwa ketiga subjek memiliki kemampuan mengidentifikasi aspek matematika dari suatu konteks masalah di kehidupan nyata dan mengidentifikasi variabel yang diketahuiyang hampir sama.

2. Pada kemampuan menentukan model matematika dan menyederhanakanmasalah,subjek NZC memiliki koding paling tinggi dibandingkan subyek RAM dan WNF. Subyek NZC memberikan informasi menentukan model matematika dan menyederhanakanmasalah sebanyak 12 kali, sedangkan subjek RAM sebanyak 3 kali dan subyek WNF sebanyak 8 kali. Hal ini mengindikasikan bahwa subjek NZC memiliki kemampuan menentukan model matematika dan menyederhanakanmasalah yang lebih baik daripada subjek RAM maupun subjek WNF, karena subjek NZC mampu secara rinci menjelaskan cara penentuan model matematika dan menyederhanakanmasalah. 
3. Pada kemampuan menyajikan kembali penyelesaianmasalah menggunakan cara yang berbeda,subjek WNF dan NZC memiliki selisih koding yang tidak banyak dan kemampuan keduanya berada dibawah subjek RAM. Subjek WNF memberikan informasipenyajian kembali penyelesaianmasalah menggunakan cara yang berbeda sebanyak 3 kali, disusul oleh subjek NZC sebanyak 4 kali, dan secara rinci dikemukakan oleh subjek RAM sebanyak 7 kali.

4. Pada kemampuan menentukan aspek konsep matematika, fakta, atau prosedur dari suatu masalah,subjek NZC memiliki kodingterbanyak kemudian disusul subjek RAM dan WNF. Subjek NZC memberikan informasipenentuan aspek konsep matematika, fakta, atau prosedur dari suatu masalah sebanyak 6 kali, disusul subjeek RAM sebanyak 5 kali dan subjek WNF sebanyak 3 kali.Subyek NZC mengetahui secara rinci terkait konsep matematika, fakta, atau prosedur dari masalah yang diberikan.

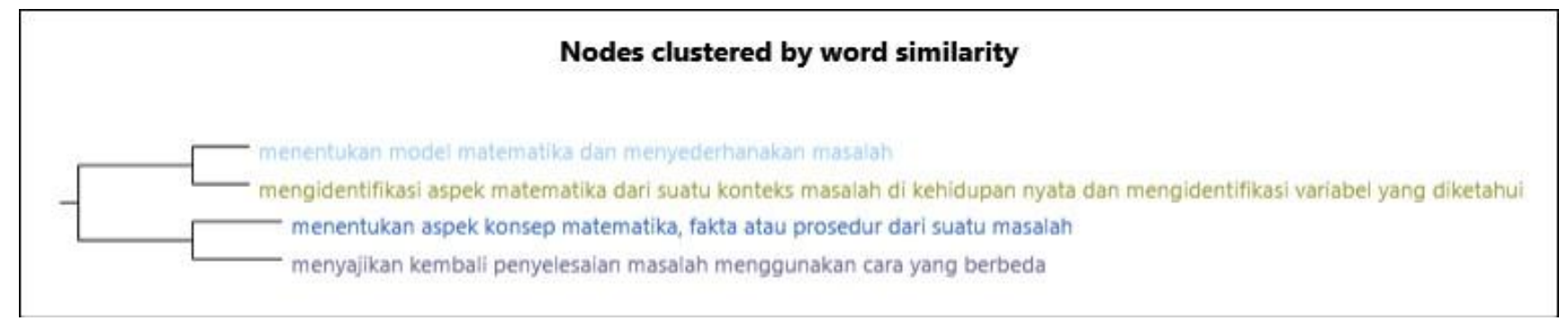

\section{Gambar 9.Cluster AnalysisLiterasi Matematika pada Tahap Merumuskan Masalah secara Matematis}

Berdasar pada Gambar 9 terlihat dua pasang node yang memiliki kemiripan.Kemiripan pertama adalahnode menentukan model matematika dan menyederhanakan masalah dengan node mengidentifikasi aspek matematika dari suatu konteks masalah di kehidupan nyata dan mengidentifikasivariabel yang diketahui. Kemiripan kedua adalah node menentukan aspek konsep matematika, fakta, atau prosedur dari suatu masalah dengannode menyajikan kembali penyelesaian masalah menggunakan cara yang berbeda.Hal ini menunjukkan bahwa kedua node yang memiliki kemiripan saling berhubungan. Siswa yang memiliki kemampuan mengidentifikasi aspek matematika dari suatu konteks masalah di kehidupan nyata dan mengidentifikasi variabel yang diketahui, juga memiliki kemampuan untuk menentukan model matematika dan menyederhanakan masalah. Begitu pula, siswa yang memiliki kemampuan menentukan aspek konsep matematika, fakta, dan prosedur dari suatu masalah, juga memiliki kemampuan dalammenyajikan kembali penyelesaian masalah menggunakan cara yang berbeda.

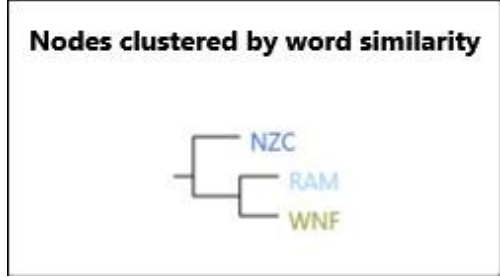

\section{Gambar 10.Cluster Analysis Subjek Penelitian}

Berdasar pada Gambar 10 ketiga subjek memiliki koefisien korelasi yang cukup tinggi (WNF-RAM $=0,807979, \mathrm{WNF}-\mathrm{NZC}=0,751566, \mathrm{RAM}-\mathrm{NZC}=0,726954)$. Terlihat kemiripan proses pemecahan masalah subjek antara subjek WNF dan RAM tetapi kedua subjek tersebut memiliki sedikit perbedaan proses pemecahan masalah dengan subjek NZC. Koefisien korelasi antar subjek penelitian menunjukkan 
hubungan yang cukup kuat, dan hal ini mengindikasikan bahwa data telah jenuh. Semua subjek penelitian telah memberikan informasi yang identikdan tidak muncul data-data baru lagi.

Salah satu hal yang perlu diperhatikan oleh setiap peneliti kualitatif adalah bagaimana mengukur akurasi atau konsistensi penelitian kualitatif (Sutrisno, Sudargo, Titi, 2019). Untuk keperluan tersebut, maka perlu diukur tingkat reliabilitas dalam penelitian ini melaluikoefisien Cohen's Kappa dengan menggunakan bantuan software QSR NVivo 11 pada fiturCoding Comparison Query.Koefisien Cohen's Kappa lebih dikenal sebagai koefisien Kappa. Uji Kappa dalam software QSR NVivo sesungguhnya diadaptasi dari statistik uji Kappa. Uji ini digunakan untuk menentukan konsistensi hasil kodingantaranggota peneliti atau tim peneliti. Koefisien Kappa memperhitungkan jumlah kesepakatan yang dapat diharapkan terjadi secara kebetulan. Hal inilah yang menjadi kelebihan dari koefisien Kappa bila dibandingkan persentase kesepakatan, sehingga banyak peneliti menganggap koefisien Kappa lebih berguna daripada angka persentase kesepakatan (Muhtarom, Murtianto, Sutrisno, 2017). Fleiss, Levis, dan Paik (2003) menyatakan bahwa koefisien kappa dapat diinterpretasikan dengan menggunakan pedoman yang tersaji pada Tabel 6 .

Tabel 6. Pedoman Interpretasi Koefisien Kappa

\begin{tabular}{cc}
\hline Nilai Kappa & Interpretasi \\
\hline Kurang dari 0,40 & Poor Agreement \\
$0,40-0,75$ & Fair to Good Agreement \\
Lebih dari 0,75 & Excellent Agreement \\
\hline
\end{tabular}

Pada penelitian ini, diperoleh koefisien kappa sebesar 0,76 dengan persentase kesepakatan 97,35\%, sehingga dapat dinyatakan bahwapenelitian ini memiliki reliabilitas yang tergolong Excellent Agreement(Kesepakatan yang Sangat Baik).

\section{PEMBAHASAN}

Pembahasan yang telah didapat mengenai literasi matematika siswa yang dilakukan oleh tiga subjek terpilih dengan kategori kemampuan tinggi pada tahap merumuskan masalah secara matematis yaitu ketiga subjek mampu merumuskan masalah secara matematis tetapi belum maksimal. Tahapan proses literasi matematika yang dicapai oleh siswa pada tahap pertama yaitu mengidentifikasi aspek matematika dari suatu konteks masalah di kehidupan nyata dan mengidentifikasi variabel yang diketahui; menentukan model matematika dan menyederhanakan masalah; serta menentukan aspek konsep matematika, fakta atau prosedur dari suatu masalah.

Hal ini sesuai Mahardiningrum (2018), yang menyatakan bahwapemecahan masalah terdiri dari tahap: (1) memahami masalah, subyek kategori tinggi dan sedang mampu menentukan apa yang diketahui dan ditanyakan dengan tepat, (2) menyusun rencana pemecahan masalah, subjek kategori tinggi dan sedang mampu menentukan keterkaitan antara informasi, (3) melaksanakan rencana pemecahan, subyek kategori tinggi dan sedang mampu menggunakan langkah-langkah melaksanakan rencana. Sari, Ikhsan, \&Saminan (2017) menunjukkan siswa pada kategori tinggi memahami permasalahan dengan baik terlihat siswa menuliskan informasi yang diberikan dengan bahasanya sendiri.

Selain itu menurut Hidayati \&Widodo (2015), Nisa (2016), Afifah (2003), Marlina (2013), Sudarman (2010),Wulantinadkk (2015), Mawaddah (2015), Agustina \& Farida (2015)mengemukakan bahwa siswa memahami masalah dengan cara membaca soal dan dapat menjelaskan masalah yang dihadapi. Jika masih belum bisa memahami masalah, siswa akan membaca dan meneliti soal lagi sampai bener-bener 
memahami masalah. Siswa dapat menyebutkan apa saja yang diketahui dan apa yang ditanyakan dari soal secara lisan dan menuliskannya pada lembar jawabannya serta dapat memberikan penjelasan dan alasan mengapa bisa menetapkan sesuatu sebagai yang diketahui dan ditanyakan yaitu dengan melihat soal karena menurutnya apa yang diketahui dan ditanyakan telah tertulis dengan jelas pada soal.

Kendala yang dihadapi oleh siswa dalam merumuskan masalah secara matematis adalah siswa belum maksimal dalam menyajikan kembali penyelesaian masalah menggunakan cara yang berbeda. Hal ini sesuai dengan yang dikemukakan oleh Prabawati (2018) bahwa mahasiswa bekemampuantinggi memenuhi semua indikator pada level 2. Mahasiswa berkemampuan tinggi mampu menafsirkan dan mengenali situasi dengan konteks yang memerlukan kesimpulan langsung. Berdasar pada hasil wawancara mahasiswa berkemampuan tinggi mampu memilah informasi yang relevan dari sumber tunggal, dan menggunakan cara penyajian tunggal serta mampu memberikan alasan secara langsung dan melakukan penafsiran yang sebenarnya. Selain itu juga dikemukakan oleh Agustina \& Farida (2015) bahwa siswa tidak dapat menyelesaikan dengan cara yang berbeda.

Berdasar pada Gambar 9 terlihat dua pasang node yang memiliki kemiripan, yang pertama yaitu menentukan model matematika dan menyederhanakan masalah dan mengidentifikasi aspek matematika dari suatu konteks masalah di kehidupan nyata dan mengidentifikasivariabel yang diketahui. Kemudian untuk kemiripan yang kedua adalah menentukan aspek konsep matematika, fakta atau prosedur dari suatu masalah dan menyajikan kembali penyelesaian masalah menggunakan cara yang berbeda. Hal ini mengindikasikan bahwa: a) siswa menentukan model matematika dan menyederhanakan masalah dan mengidentifikasi aspek matematika dari suatu konteks masalah di kehidupan nyata dan mengidentifikasivariabel yang diketahui, b) siswa mampu adalah menentukan aspek konsep matematika, fakta atau prosedur dari suatu masalah dan menyajikan kembali penyelesaian masalah menggunakan cara yang berbeda.Secara umum siswa kelas VIII yang berkemampuan tinggi sudah memenuhi indikator kemampuan literasi pada tahap merumuskan masalah secara matematis. Walaupun ada beberapa sub indikator yang belum terpenuhi, kecenderungan siswa sudah memenuhi kemampuan literasi matematika.

\section{SIMPULAN}

Hasil penelitian menunjukkan bahwa proses literasi matematika siswa dengan kemampuan tinggi pada tahap merumuskan masalah secara matematis yaitu mengidentifikasi aspek matematika dari suatu konteks masalah di kehidupan nyata dan mengidentifikasi variabel yang diketahui; menentukan model matematika dan menyederhanakan masalah; serta menentukan aspek konsep matematika, fakta atau prosedur dari suatu masalah.

\section{UCAPAN TERIMA KASIH}

Kepala Sekolah SMP Negeri 3 Purwodadi yang telah memberi saya izin untuk melakukan penelitian dan mempersilakan pengambilan data dengan baik. Siswa-siswa SMP Negeri 3 Purwodadi khususnya kelas VIII C yang bersedia berkontribusi dalam penelitian dan semua pihak yang membantu saya dalam melancarkan penelitian di SMP Negeri 3 Purwodadi.

\section{DAFTAR RUJUKAN}

Afifah, D. S. (2013). Profil Metakognisi Siswa dalam Menyelesaikan Soal Sistem Persamaan Linear Dua Variabel Berdasarkan Gaya Kognitif. Jurnal Pendidikan Matematika STKIP PGRI Sidoarjo, 1. 
Agustina, R., \& Farida, N. (2015). Proses Berpikir Siswa SMK dalam Menyelesaikan MAsalah Matematika Ditinjau dari Kepribadian Phlegmatis. Jurnal Pendidikan Matematika FKIP Univ. Muhammadiyah Metro, 4.

Aini, R. N. (2014). Analisis Pemahaman Siswa SMP dalam Menyelesaikan Masalah Aljabar pada PISA. Jurnal Ilmiah Pendidikan Matematika.

Asmara, D. (2017). Analisis Kemampuan Literasi Matematika Siswa Kelas X Berdasarkan Kemampaun Matematika. Scholaria, 7, 135-142.

Fleiss, J., Levin, B., Paik, M. (2003). Statistical Methods for Rates and Proportions. New York: Wiley \& Sons.

Hidayati, A., \& Widodo, S. (2015). Proses Penalaran Matematis Siswa dalam Memecahkan Masalah Matematika pada Materi Pokok Dimensi Tiga Berdasarkan Kemampuan Siswa Di SMA Negeri 5 Kediri. Jurnal Math Educator Nusantara, 01.

Kementrian Pendidikan dan Kebudayaan. 06 Desember, 2016. Hasil Survei PISA : Peningkatan Capaian Indonesia Termasuk Empat Besar.

Mahardiningrum, A. S., \& Ratu, N. (2018). PROFIL Pemecahan Masalah Matematika Siswa SMP Pangudi Luhur Salatiga Ditinjau dari Berpikir Kritis . Mosharafa.

Marlina, L. (2013, September). Penerapan Langkah Polya dalam Menyelesaikan Soal Cerita Keliling dan Luas Persegi Panjang. Jurnal Elektronik Pendidikan Matematika, 01.

Mawaddah, S., \& Anisah, H. (2015). Kemampuan Pemecahan Masalah Matematis Siswa padaPembelajaran Matematika dengan Menggunakan Model Pembelajaran Generatif (Generative Learning) Di SMP. Jurnal Pendidikan Matematika.

Muhtarom, M., Murtianto, Y. H., \&Sutrisno, S. (2017). Thinking Process of Students with HighMathematics Ability (A Study on QSR NVivo 11-Assisted Data Analysis). International Journal of Applied Engineering Research, 12(17), 6934-6940.

Nisa, H. M., Sa'dijah, C., \& Qohar, A. (2016). Kemampuan Pemecahan Masalah Matematika Siswa SMK Bergaya Kognitif Field Dependent. Prpsiding Seminar Matematika dan Pendidikan Matematika.

OECD. (2013). PISA 2012 Assessment and Analytical Framework: Mathematics, Reading, Science, Problem Solving and Financial Literacy. Paris: OECD Publishing.

OECD. (2014). PISA 2012 Results in Focus: What 15-year-olds Know and What They Can Do With What They Know. OECD Publishing. Dari: http://www.oecd.org/pisa/keyfindings/pisa-2012-resultoverview.pdf.

Prabawati, M. N. (2018). Analisis Kemampuan Literasi Matematika Mahasiswa Calon Guru Matematika. Mosharafa. 
Sari, A. P., Ikhsan, M.\& Saminan. (2017). Proses Berpikir Kreatis Siswa dalam Memecahkan Masalah Matematika Berdasarkan Model Wallas. Jurnal Tadris Matematika, 10, 18-32.

Sari, Rosalia Hera Novita. (2015). Literasi Matematika : Apa, Mengapa dan Bagaimana?. Makalah disajikan dalam Seminar Nasional Matematika dan Pendidikan Matematika, Universitas Negeri Yogyakarta, ISBN 978-60273403-0-5.

Sudarman. (2010). Proses Berpikir Siswa SMP Berdasarkan Adversity Quotient (AQ) dalam Menyelesaikan Masalah Matematika. Surabaya: Universitas negeri Surabaya.

Sutrisno, S., Sudargo, S., \& Titi, R.A. (2019). Analisis Kemampuan Representasi Matematis Siswa SMK Kimia Industri Theresiana Semarang. JIPMat (Jurnal Ilmiah Pendidikan Matematika), 4(1), 65-76.

Wulantina, E, Kusmayadi, T.A, \& Riyadi. (2015). Proses berpikir kreatif siswa dalam pemecahan masalah matematika ditinjau dari kemampuan matematika pada siswa kelas X MIA SMAN 6 Surakarta. Jurnal Elektronik Pembeleajaran Matematika. 3 (6), 671-682. 